\title{
VIABILITY AND DISCRIMINATION OF AVIAN PERIPHERAL BLOOD MONONUCLEAR CELLS AND THROMBOCYTES INTENDED FOR IMPROVEMENT OF WOUND HEALING IN BIRDS
}

\author{
Dagmar MUdROŇOVÁ*, Martin KoŽÁR, Ladislav MOLNÁR and Alexandra TRBOLOVÁ \\ University of Veterinary Medicine and Pharmacy, Komenského 73, 0481 Košice, \\ Slovak Republic
}

(Received 7 October 2013; accepted 12 March 2014)

\begin{abstract}
Birds often suffer from skin injuries of different aetiology. Platelet-rich plasma (PRP) is successfully used for improvement of wound healing in humans and in some mammalian species (e.g. horses, dogs and cats), but experience with its application in avian patients has not yet been published. Therefore, the aim of this study was to test a quick method for the counting of isolated avian platelets and mononuclear leukocytes and to find an appropriate carrier for their application to the wounds of birds. It seems that flow cytometry can be used for the quick counting of isolated cells and the discrimination of thrombocytes, lymphocytes and eventually monocytes or debris. Of the tested gels and sponges routinely used for improvement of wound healing, a gelatin sponge $\left(\right.$ Gelaspon $\left.{ }^{\circledR}\right)$ providing the highest numbers and viability of isolated cells proved to be the best carrier.
\end{abstract}

Key words: Platelet-rich plasma, birds, thrombocytes, skin wounds, flow cytometry

Avian patients rather often suffer from skin injuries of different aetiology (e.g. trauma, dermatologic diseases). The skin of birds is thinner and more delicate than that of mammals, therefore it is more sensitive to damage (Burke et al., 2002). Older, contaminated or large-sized wounds with lack of adjacent tissue should be treated by open-wound therapy, which involves the use of topical antimicrobial products, wound-healing stimulants, different types of occlusive dressings or protective bandages. Despite the unique anatomy of avian skin, the mechanism of wound healing is similar to that known in mammals (Ritzman, 2004). After an injury, the first-phase inflammation is initiated, followed by proliferation and remodelling. The healing of wounds is regulated by several cell types (leukocytes, platelets, fibroblasts, etc.) and by numerous cytokines and growth factors. For the treatment of different types of wounds it is very important to increase the dermal and epidermal regeneration rate which is influenced

\footnotetext{
*Corresponding author; E-mail: mudronova@uvlf.sk; Phone: 00421 (915) 986-954
} 
by several factors, such as the extent of tissue damage, bacterial contamination or the patient's individual healing ability (Tóth et al., 1998; Petelin et al., 2004; Ritzman, 2004). In human medicine, platelet-rich plasma (PRP) is successfully used for the improvement of wound healing (Lozada et al., 2001; Torres et al., 2010). PRP contains a high concentration of platelets as well as angiogenic and mitogenic growth factors implicated in wound healing, which are produced by platelets and macrophages. Among the growth factors, transforming growth factor- $\beta$ and platelet-derived growth factor play a key role in the wound healing process (Theoret, 2005). PRP is easily obtained from mammalian whole blood by centrifugation. Since avian thrombocytes are nucleated cells, similar in size and density to lymphocytes and monocytes, they are obtained by the density gradient $\left(1.077 \mathrm{~g} / \mathrm{cm}^{3}\right)$ together with peripheral blood mononuclear cells (PBMC) (Bertram, 1998). Thrombocytes can be counted and discriminated from lymphocytes by flow cytometry based on the use of specific monoclonal antibodies (e.g. K55-low population corresponds to platelets) or the difference in inside granularity of avian platelets and lymphocytes (Bertram, 1998; Bohls et al., 2006). Because most avian monoclonal antibodies are only specific and produced for poultry cell markers, it is not possible to use them for other avian species. Moreover, they are expensive. Since avian thrombocytes possess higher granularity than lymphocytes, due to the presence of cytoplasmic inclusions and vacuoles, they can be distinguished from lymphocytes by their increased side-scatter profile (Bertram, 1998). Flow cytometry using specific fluorescent dyes is also a powerful tool for testing the viability of different cells. There is a range of fluorescent dyes that can be used for characterising the metabolic status of cells. One of the most widely used dyes is propidium iodide, an orange/red fluorescent nucleic acid stain that is membrane impermeable and so can only stain cells with compromised membranes (Hoefel et al., 2003; Jankovičova et al., 2008). The aim of this study, therefore, was to test a quick flow cytometric method for counting and evaluating the viability of isolated avian platelets and mononuclear leukocytes and to find an appropriate carrier for their application to the wounds of birds.

\section{Materials and methods}

\section{Isolation of PBMC and thrombocytes}

One $\mathrm{ml}$ of blood was taken from the jugular vein of 15 healthy domestic fowl (Gallus domesticus) of the ISA brown hybrid, about 1.5 years of age, into tubes containing heparin $(25 \mathrm{IU} / \mathrm{ml})$. Peripheral blood mononuclear cells (PBMC) were isolated using Lymphocyte Separation Medium LSM 1077 (PAA Laboratories $\mathrm{GmbH}$, Austria). One $\mathrm{ml}$ of blood was diluted 1:1 in phosphate buffered saline (PBS; $137 \mathrm{mM} \mathrm{NaCl}, 2.7 \mathrm{mM} \mathrm{KCl}, 6.4 \mathrm{mM} \mathrm{Na} 2 \mathrm{HPO}_{4}, 1.2 \mathrm{mM} \mathrm{KH}_{2} \mathrm{PO}_{4}$ in distilled water, $\mathrm{pH} 7.3$, filtered through a $0.22-\mu \mathrm{m}$ filter) and underlaid with $3 \mathrm{ml}$ 
of LSM 1077. The tubes were centrifuged for $25 \mathrm{~min}$ at $600 \times \mathrm{g}$. After centrifugation, the PBMC interface was collected and transferred to a new 12-ml tube. Cells were washed twice with PBS and centrifuged for 5 min at $250 \times \mathrm{g}$. Finally, the sediment of PBMC was resuspended in $0.5 \mathrm{ml}$ of PBS.

\section{Tested carriers for isolated cells}

As potential carriers, three types of gels - Solcoseryl jelly (Valeant, Switzerland), Askina gel (B. Braun, Germany), Lavanid-Wundgel (Serag Wiessner, Germany) - and three types of sponges - Biopad (Euroresearch, Italia), Gelaspon (Chauvin Ankerpharm GmbH, Germany), and Gelitaspon (Gelita Medical BV, The Netherlands) - routinely used for the improvement of wound healing were tested. Control samples were incubated in Dulbecco's modified Eagle's medium DMEM (PAA Laboratories GmbH, Pasching, Austria). Before the testing of viability, isolated PBMC were mixed together to obtain a uniform suspension of cells. Half a millilitre of PBMC suspension was mixed with $0.5 \mathrm{ml}$ of the appropriate gel or infused in $1 \mathrm{~cm}^{3}$ of sponge.

\section{Flow cytometric analysis of cell viability and counts}

The viability and number of cells were tested before placing PBMC on the carriers and subsequently 2, 4 and $24 \mathrm{~h}$ after mixing, during incubation at laboratory temperature. A $25-\mu 1$ volume of the prepared suspension was mixed with $225 \mu \mathrm{l}$ of propidium iodide (PI) working solution with a concentration of $6 \mu \mathrm{g} \mathrm{PI} / \mathrm{ml}$ of PBS, and incubated for $15 \mathrm{~min}$ at $37^{\circ} \mathrm{C}$. Flow cytometric analysis of the viability was performed in a BD FACSCanto ${ }^{\mathrm{TM}}$ flow cytometer (Becton Dickinson Biosciences, USA) using BD FACS Diva ${ }^{\mathrm{TM}}$ software. Fluorescence measurements were carried out using 488-nm blue laser with Fl-3 filter $(695 / 40 \mathrm{~nm})$. The position of cells was gated in forward scatter (FSC) vs. side scatter (SSC) dot plot. An Fl-3 histogram was used to determine the percentages of live and dead cells. Cells were counted at low flow rate $(10 \mu \mathrm{l} / \mathrm{min})$ during $30 \mathrm{sec}$. Chicken lymphocytes and thrombocytes were discriminated on the basis of their different SSC profiles. Cells with an increased side scatter correspond to thrombocytes, while those with a lower SSC were lymphocytes (Bertram, 1998).

\section{Statistical analysis}

Data were evaluated using the GraphPad Prism version 3.00 software by one-way analysis of variance (ANOVA) followed by Dunnett's test. 


\section{Results}

After the isolation, we obtained approximately $7 \times 10^{5}$ PBMC containing thrombocytes in one $\mathrm{ml}$. Thrombocytes represented approximately $45-50 \%$ of the isolated cells, i.e. $3.15-3.5 \times 10^{5}$ cells $/ \mathrm{ml}$. We found that the numbers of these cells significantly decreased during incubation in some carriers (Table 1).

Table 1

Numbers of chicken peripheral blood mononuclear cells (PBMC) containing thrombocytes placed in different carriers expressed as numbers of cells $\times 10^{5} / \mathrm{ml} \pm \mathrm{SD}(\mathrm{n}=3)$ after incubation at laboratory temperature

\begin{tabular}{lcccc}
\hline \multirow{2}{*}{ Carrier } & \multicolumn{4}{c}{ Incubation period } \\
\cline { 2 - 5 } & $0 \mathrm{~h}$ & $2 \mathrm{~h}$ & $4 \mathrm{~h}$ & $24 \mathrm{~h}$ \\
\hline DMEM - control & $7.0 \pm 0.16$ & $7.1 \pm 0.16$ & $7.0 \pm 0.31$ & $5.0 \pm 0.14$ \\
Solcoseryl gel & $7.0 \pm 0.16$ & $4.2 \pm 0.21^{*}$ & $2.3 \pm 0.50^{* *}$ & $1.5 \pm 0.21^{* *}$ \\
Askina gel & $7.0 \pm 0.16$ & $3.1 \pm 0.50^{* *}$ & $3.2 \pm 0.64^{* *}$ & $0.8 \pm 0.12^{* *}$ \\
Biopad & $7.0 \pm 0.16$ & $4.0 \pm 1.45^{*}$ & $1.3 \pm 0.36^{* *}$ & $0.07 \pm 0.02^{* *}$ \\
Gelaspon & $7.0 \pm 0.16$ & $6.1 \pm 0.26$ & $6.0 \pm 0.12^{* *}$ & $5.7 \pm 0.25^{* *}$ \\
Gelitaspon & $7.0 \pm 0.16$ & $4.9 \pm 1.25$ & $3.1 \pm 0.6^{* *}$ & $2.7 \pm 0.22^{* *}$ \\
ANOVA & $\mathrm{P}>0.05$ & $\mathrm{P}=0.0041$ & $\mathrm{P}<0.0001$ & $\mathrm{P}<0.0001$ \\
\hline
\end{tabular}

${ }^{*}$ significantly different from control $(\mathrm{P}<0.05) ;{ }^{* *}$ significantly different from control $(\mathrm{P}<0.01)$

Table 2

Viability of chicken PBMC containing thrombocytes placed in different carriers expressed in percentages of live cells $\pm \mathrm{SD}(\mathrm{n}=3)$ after incubation at laboratory temperature

\begin{tabular}{lcccc}
\hline \multirow{2}{*}{ Carrier } & \multicolumn{4}{c}{ Incubation period } \\
\cline { 2 - 5 } & $0 \mathrm{~h}$ & $2 \mathrm{~h}$ & $4 \mathrm{~h}$ & $24 \mathrm{~h}$ \\
\hline DMEM - control & $97.7 \pm 0.08$ & $97.7 \pm 0.22$ & $98.0 \pm 0.54$ & $97.3 \pm 0.09$ \\
Solcoseryl gel & $97.7 \pm 0.08$ & $96.0 \pm 0.82^{*}$ & $95.3 \pm 0.56^{*}$ & $7.50 \pm 3.43^{* *}$ \\
Askina gel & $97.7 \pm 0.08$ & $90.6 \pm 1.10^{* *}$ & $18.4 \pm 8.20^{* *}$ & $0.20 \pm 0.05^{* *}$ \\
Biopad & $97.7 \pm 0.08$ & $95.3 \pm 0.51^{* *}$ & $92.1 \pm 0.37^{*}$ & $\mathrm{NM}$ \\
Gelaspon & $97.7 \pm 0.08$ & $97.8 \pm 0.22$ & $97.6 \pm 0.59$ & $97.3 \pm 0.37$ \\
Gelitaspon & $97.7 \pm 0.08$ & $97.6 \pm 0.12$ & $97.5 \pm 0.21$ & $95.1 \pm 0.45$ \\
ANOVA & $\mathrm{P}>0.05$ & $\mathrm{P}<0.0001$ & $\mathrm{P}<0.0001$ & $\mathrm{P}<0.0001$ \\
\hline
\end{tabular}

${ }^{*}$ significantly different from control $(\mathrm{P}<0.05) ;{ }^{* *}$ significantly different from control $(\mathrm{P}<0.01)$. NM: not measurable

The most evident decrease was noted in the Biopad and Askina gels, where only $7 \times 10^{3}$ and $8 \times 10^{4}$ cells $/ \mathrm{ml}$ were counted after $24 \mathrm{~h}$. In contrast, the highest numbers of cells were found in Gelaspon. In the same way as for the cell counts, the highest viability of cells after $24 \mathrm{~h}$ was found in Gelaspon and Geli- 
taspon (Table 2). Due to the very low numbers of cells after $24 \mathrm{~h}$ of incubation, it was not possible to measure their viability accurately in Biopad sponge. The lowest viability after 2, 4 and $24 \mathrm{~h}$ was measured in Askina gel. Unfortunately, it was not possible to perform these measurements in the Lavanid gel, probably due to conglutination of the cells by the gel. Even if the cells were measured immediately after being mixed with this gel, they were not found in their normal position on FSC vs. SSC dot plot.

\section{Discussion}

In this study we tested different carriers appropriate for the application of cell concentrates for the improvement of wound healing in birds. The viability of isolated cells in the carriers tested depends on their composition. With the exception of Lavanid gel containing polyhexanide which inhibits the growth of microorganisms, the other carriers tested do not contain antimicrobial substances. Despite this fact, their composition significantly influenced the viability of isolated cells. The highest viability was noted in Gelaspon and Gelitaspon, both of which sponges are made of $100 \%$ purified porcine gelatin. On the other hand, significantly lower viability was found in Biopad sponge constituted exclusively by lyophilised type I native heterologous equine collagen. Since Gelitaspon is not suitable for closing of skin wounds because of a possible disruption of the wound healing process, Gelaspon was chosen as the best carrier for the subsequent experiments. The treatment of skin wounds based on the use of PRP containing mononuclear cells and Gelaspon as a carrier should be used in the practice first of all in rare exotic and pet birds and birds of prey. In such individual avian patients, we can take blood and prepare a cell concentrate for open-wound therapy within one hour. Flow cytometry seems to be very useful for the quick counting of isolated cells and for the discrimination of thrombocytes, lymphocytes and eventually monocytes or debris based on differences in their morphology. Despite the fact that avian lymphocytes and thrombocytes are similar in shape (oval to round) and size (4-8 $\mu \mathrm{m})$, they can be distinguished by flow cytometry based on the difference in cell complexity. Avian lymphocytes are non-granular cells with a large round nucleus and little cytoplasm, while thrombocytes contain cytoplasmic inclusions and vacuoles (Daimon and Uchida, 1978), which increase their side-scatter profile. Moreover, after simple staining with propidium iodide, a fluorescent dye which can enter only cells having a damaged membrane, it is possible to count the live and dead cells simultaneously.

In conclusion, it seems that flow cytometry represents an appropriate method for the quick counting of isolated cells as well as for the discrimination of thrombocytes, lymphocytes and eventually monocytes or debris. Of the tested gels and sponges routinely used for the improvement of wound healing, the best carrier was a gelatin sponge - Gelaspon $^{\circledR}-$ which provided the highest numbers and viability of isolated cells. 


\section{Acknowledgement}

The research activities and authors of this study were supported by the EU structural fund ITMS 26220220185 (Medipark).

\section{References}

Bertram, E. M. (1998): Characterization of duck thrombocytes. Res. Vet. Sci. 64, 267-270.

Bohls, R. L., Smith, R., Ferro, P. J., Silvy, N. J., Li, Z. and Collisson, E. W. (2006): The use of flow cytometry to discriminate avian lymphocytes from contaminating thrombocytes. Dev. Comp. Immunol. 30, 843-850.

Burke, H. F., Swaim, S. F. and Amalsadvala, T. (2002): Review of wound management in raptors. J. Avian Med. Surg. 16, 180-191.

Daimon, T. and Uchida, K. (1978): Electron microscopic and cytochemical observation on the membrane system of the chicken thrombocyte. J. Anat. 125, 11-21.

Hoefel, D., Grooby, W. L., Monis, P. T., Andrews, S. and Saint, C. P. (2003): Enumeration of water-borne bacteria using viability assays and flow cytometry: a comparison to culture-based techniques. J. Microbiol. Methods 55, 585-597.

Jankovičova, J., Simon, M., Antalíkova, J. and Horovská, L. (2008): Acrosomal and viability status of bovine spermatozoa evaluated by two staining methods. Acta Vet. Hung. 55, 133-137.

Lozada, J. L., Caplanis, N., Proussaefs, P., Willardsen, J. and Kammeyer, G. (2001): Platelet-rich plasma application in sinus graft surgery: Part I - background and processing techniques. J. Oral Implantol. 27, 38-42.

Petelin, M., Pavlica, Z., Batista, U., Stiblar-Martincic, D. and Skaleric, U. (2004): Effects of periodontal dressings on fibroblasts and gingival wound healing in dogs. Acta Vet. Hung. 52, 33-46.

Ritzman, T. K. (2004): Wound healing and management in psittacine birds. Vet. Clin. Exot. Anim. $7,87-104$.

Theoret, C. L. (2005): The pathophysiology of wound repair. Vet. Clin. N. Am. Equine Pract. 21, $1-13$.

Torres, J., Tamimi, F., Alkhraisat, M. H., Manchón, A., Linares, R., Prados-Frutos, J. C., Hernández, G. and López Cabarcos, E. (2010): Platelet-rich plasma may prevent titaniummesh exposure in alveolar ridge augmentation with anorganic bovine bone. J. Clin. Periodontol. 37, 943-951.

Tóth, E., Farkas, R., Márialigeti, K. and Mokhtar, I. S. (1998): Bacteriological investigations on wound myiasis of sheep caused by Wohlfahrtia magnifica (Diptera: Sarcophagidae). Acta Vet. Hung. 46, 219-229. 